\title{
Determining the Predictors of Self-Efficacy and Cyber Bullying
}

\author{
Tuğba Y1lmaz Bingöl $1^{1}$ \\ ${ }^{1}$ Fatih Sultan Mehmet Foundation University, Turkey \\ Correspondence: Tuğba Yılmaz Bingöl, Fatih Sultan Mehmet Foundation University, Istanbul, Turkey. E-mail: \\ tbingol@fsm.edu.tr
}

Received: February 16, 2018

Accepted: March 6, 2018

Online Published: March 23, 2018

doi:10.5430/ijhe.v7n2p138

URL: https://doi.org/10.5430/ijhe.v7n2p138

\begin{abstract}
In this study, it was aimed to determine the variables affecting self-efficacy and cyber bullying. The participants of the study were 223 high school students. The data was collected through the use of self-administered questionnaires which were the General Self-efficacy Scale, the Gratitude Scale, the Early Memories of Warmth and Safeness Scale and the Revised Cyber Bullying Inventory. Results of structural equation modeling analysis revealed that self-efficacy was affected by early memories of warmth and safeness and cyber bullying was affected by being a cyber victim. All goodness of fit indices of the model in this study was satisfactory. The results of the study demonstrated the importance of early memories of warmth in improving self-efficacy and preventing cyber victimization is effective in decreasing cyber bullying.
\end{abstract}

Keywords: self-efficacy, cyber bullying, gratitude, early memories

\section{Introduction}

Adolescence which is one of the most difficult and critical phases of the life span brings with it many challenges. Adolescents experience many cognitive, emotional, physical and social changes. These changes can lead to an increase in the level of risky behaviors which may be potentially harmful to an individual and stress. Hall (1904) conceptualized adolescence in which an individual experiences conflict between being a child and being an adult, as a period of stress and turmoil. The increase of use of internet in adolescence leads cyber bullying.

Cyber bullying, which has increased with the widespread use of technology, can be defined as intentional harm doing and sequential aggressive behaviors by one person or a group through codes and algorithms (Patchin, \& Hinduja, 2006, p.148). According to Arıcak (2009, p. 168) cyber bullying includes ringing from a private number, sending spam emails, sending insulting or slandering e-mail messages which involve voice, text or photograph, sending blackmail, spreading of rumors through social media and all these kinds of activities. Cyber victimization is moral damage, emotional distress and pecuniary loss which are experienced by a person or group as a result of being exposed to any act of aggression and snide behavior through computers or other technological devices (Arıcak, Tanrıkulu, \& Kinay, 2012).

Cyber bullying as an aggressive behavior has emerged in the last decade in several countries which utilize the internet and online technologies actively such as the United States of America. Due to the fact that it is a common problem among young people and has more harmful effects than expected, researchers (Aricak, 2009; Li, 2006, 2007) rapidly paid attention to this phenomenon. Cyber bullying has become a major problem for educators in the United States. Studies (David-Ferdon \& Hertz, 2007) indicated that students in grade 6-12 are exposed to cyber bullying at least one time in their lives. This may cause students to decrease in grades, dropout and even attempt suicide. Peker, Eroğlu and Ada (2012) revealed that cyber bullying and cyber victimization are common problems among students also in Turkey.

Research by Dilmaç (2009) indicated that cyber bullying is associated with significant health problems and psychological problems among young people such as depression, low self-confidence, emotional disruption and academic failure. Akça-Baştürk, Sayımer and Ergül's (2015) research was conducted with 1400 students are studying in middle school 7th and 8th grades and live in Istanbul, Samsun, Ankara, Van, Gaziantep, Izmir and Adana. The researchers conducted surveys and interviews about the internet use of students and the problems they experienced while using the internet and aimed to raise awareness of students about cyber bullying and to prevent such behaviors. As a result of the study, it was seen that most of the students had Internet-connected computers at home, most of them visited social networks at least once a day and Facebook was the most used social network. The 
study reported that $9.5 \%$ of the students were cyber victims, $7 \%$ were cyber bullies and $7.5 \%$ were both cyber bullies and cyber victims. In other words, $24 \%$ of the students were involved in cyber bullying. In terms of gender, it was found that males were significantly more likely to get involved cyber bullying and online hate groups than females.

Self-efficacy, which can be defined (Bandura, 1994, p. 8) as beliefs that an individual has about his/her skills or capability of performing a specific set of actions, is also an important construct in adolescence. Adolescence (Santrock, 2014, p,129) is a transition period from childhood to adulthood and process of adapting to physical, emotional and social changes and responsibilities and often characterized by several difficulties. Adolescents defined their self in an idealistic way. Their perception of self-efficacy levels as high can be explained defining themselves in an idealistic way. According to Bandura (1986), self-efficacy beliefs are important indicators of one's way of acting. Adolescent changes are important to learn to manage problems in dating and sexual relationships and to develop self-efficacy. Because although not directly, pubertal changes and psycho-social factors such as biological maturation, physical superiority, and social status affect the development of self-efficacy beliefs (Bandura, 1997). Self-efficacious individuals know how to manage situations when they face life difficulties and can cope with situations that involve risky behaviors (Bandura, 1986).

Negative experiences in childhood, such as poverty, interparental conflict, divorce, parental alcoholism and mental problems may have an adverse effect on the development of self-efficacy beliefs. The quality of parental care is an important factor to develop social bonds and to manage risky situations (Bandura, 1997). Self-efficacy beliefs are rooted in the sense of confidence provided by the caregiver; as children develop positive attitudes, they receive support from the tolerant behavior of adults (Bandura, 1997). According to Clever, Walker and Meadows (2004), infancy and childhood are developmental periods when an individual experience the sense of gratitude intensely both as subject and object. The fact that the families meet all the material / spiritual needs of the child who comes to the world without any expectation and the unrequited love and interest supports the psychological health and development of the child (Erikson, 1984). According to Klein (1999), gratitude begins to emerge in infancy. The gratitude or envy of the individual in the process of object relations established by his mother during his early life contributes to the ability to solve the psychological problems encountered in the individual's personality and future life. Then in the peer groups the children are taught to establish and maintain a relationship that takes into account both their expectations and their friends' expectations, and therefore the gratitude experience (Dunn, 2004; Richter, Gilbert, \& McEvan, 2009). Therefore, it can be said that early experiences and memories are crucial. While neglected environments increase the vulnerability to psychological problems, supportive and secure environments promote high self-confidence and happiness (McCay, \&Fanning, 2014). Children develop various perceptions and emotions for their family members by internalizing the memories of interactions in the family. The perceptions and feelings of children about their family members and the people around them are also the basis of their experiences with their family interactions (Evirgen, 2010). It can be said that adolescents who don't have a healthy basis are likely to display risky behavior such as substance abuse, violence.

Based on the explanations given above, this study aims to examine the direct relationship of self-efficacy and cyber victimization and the indirect relationship of gratitude and early memories of warmth on cyber bullying which is a growing problem, especially among adolescents through structural equation modeling.

\section{Method}

\subsection{Participants}

The sample of the study was determined by simple random sampling method. The volunteering of the participants is essential. The participants of the study comprise 223 high school students who are studying in Bakırköy, Istanbul and all the participants are 11th-grade students. Of the participants $172(\% 77.1)$ were female and 51 were male (\%22.9). The survey was conducted in 2017.

\subsection{Data Collection Tools}

The General Self-Efficacy Scale (Piko, Gibbons, Luszczynska, \& Teközel, 2002), the Gratitude Scale (Akin, \& Yuksel, 2011), the Early Memories of Warmth and Safeness Scale (Akin, Uysal, \& Çitemel, 2013) and the Revised Cyber Bullying Inventory (Topçu, Erdur-Baker, 2010) were used to collect the data in the study. these scales were chosen to contribute to the literature by determining the direct and indirect relations of concepts with each other.

General Self-Efficacy Scale (Piko, Gibbons, Luszczynska, \& Teközel, 2002): Self-efficacy level of the participants was measured with the General Self-Efficacy Scale (GSES) which was developed by Schwarzer, and Jerusalem (1995) and was validated for high school students by Piko, Gibbons, Luszczynska and Teközel (2002). The GSES which measures perceived general self-efficacy to cope with difficulties is composed of 10 items. Each item in the 
scale is answered on a 4-point Likert-type scale (1: not at all true to 4: exactly true). The Cronbach alpha internal consistency of the GSES was found .82 .

Gratitude Scale: The Gratitude Scale (GS) was developed to determine the level of gratitude of individuals by McCullough, Emmons, and Tsang (2002). The GS which has a single factor is a 7-point Likert-type scale. The scale consists of six items. The GS has been adapted to Turkish by Akin and Yuksel (2011). Items 3 and 6 are reverse coded and scores range from 6 to 42. Cronbach alfa coefficient of Turkish version of the GS was calculated as .73

Early Memories of Warmth and Safeness Scale: The Early Memories of Warmth and Safeness Scale (EMWSS) was developed by Richter, Gilbert and McEwan, (2009) to measure one's positive feelings, emotions and experiences in childhood. The EMWSS consists of 20 items and each item was presented a 5-point Likert scale. A sum of all scores yields a total score that ranges from 20 to 100.Turkish adaptation of this scale has been done by Akın, Uysal and Çitemel (2013). Cronbach alfa coefficient of Turkish version of the EMWSS was calculated as .88.

Revised Cyber Bullying Inventory: The Revised Cyber Bullying Inventory (RCBI) was developed by Topçu and Erdur-Baker (2010) to assess the cyber bullying and cyber victimization experiences of adolescents. The 14-item scale consists of two parallel forms (cyber bullying and cyber victimization). Each item in the scale is answered on a 4-point Likert-type scale. The internal consistency coefficients of two subscales were .82 and .75 respectively.

\subsection{The Analysis of Data}

The data obtained in the study were analyzed using SPSS 23 and AMOS 23 statistical software. A path analysis was conducted to test the hypothesized model self-efficacy and cyber bullying. Each hypothesis was tested at .05 level of significance.

\section{Results}

The mean scores and standard deviation scores of the participants' responses are shown in Table 1.

Table 1. The mean scores and standard deviation scores of the participants

\begin{tabular}{llll}
\hline & $\mathrm{N}$ & Mean & $\mathrm{Sd}$ \\
\hline Self-efficacy & 223 & 33.18 & 4.861 \\
\hline Gratitude & 223 & 25.21 & 7.604 \\
\hline EMWS & 223 & 80.67 & 15.080 \\
\hline Cyber bullying & 223 & 18.65 & 7.653 \\
\hline Cyber victimization & 223 & 17 & 6.937
\end{tabular}

As it seen in Table 1, the mean self-efficacy scores of the participants is 33.18 (sd $=4.861)$. The highest score that can be obtained from the GSES is 40. Therefore, it can be said that mean scores demonstrated that participants tended to exhibit a high level of self-efficacy. A higher score obtained from GS indicates a higher level of gratitude. Therefore, mean scores demonstrated that participants tended to exhibit a moderate level of gratitude $(\mathrm{M}=25.21, \mathrm{Sd}=7.604)$. A higher score obtained from EMWSS indicates more recall of positive feelings, emotions and experiences in childhood. Therefore, mean scores demonstrated that participants tended to have a higher level of positive childhood memories $(M=80.67, \mathrm{Sd}=15.080)$. A higher score obtained from RCBI indicates the experiences of the cyber bullying and cyber victimization. Therefore, mean scores demonstrated that participants tended to experience low level of cyber bullying $(\mathrm{M}=18.65, \mathrm{SD}=7.653)$ and cyber victimization $(\mathrm{M}=17, \mathrm{Sd}=$ 6.937). In the current study, Cronbach's alphas of the scales were found $.84, .69, .94, .87$ and .82 respectively.

It was examined whether the data obtained for each scale varied according to sex. The scores obtained from self-efficacy, gratitude, EMWS and cyber bullying scales did not differ according to sex ( $p>.05$ ), but the scores obtained from cyber victim scale differ according to sex $(\mathrm{p}<.05)$. The scores obtained by the girls on the scale of cyber victim were significantly higher $($ Mean $=42.7, \mathrm{sd}=23.61)$ than the males $($ Mean $=31.3$, $\mathrm{sd}=23.61$ ).

According to the results of the structural equation modeling done by the researcher (Figure 1) it is found that the effect of gratitude on self-efficacy is .06 (p>.05); the effect of early memories of warmth and safeness and self efficacy is $.28(p<.01)$; and the effect of cyber victimization on self-efficacy is .-02 ( $>.05)$. While the effect of self-efficacy on cyber bullying is .05 ( $p>.05$ ), the effect of cyber victimization on cyber bullying is .50 ( $p<.01)$. Early memories of warmth and safeness have a significant influence on self-efficacy and cyber victimization has a significant impact on cyber bullying. In addition, results also suggested that the model fit well $\left(\mathrm{x}^{2} / \mathrm{df}=1.27 ; \mathrm{p}=.28\right.$, 
RMSEA=.03; GFI=.99; AGFI=.96; NFI=.98; CFI=.99). On the suggested model, gratitude, early memories of warmth and safeness and cyber victimization accounted for $10 \%$ of the variance of self efficacy. The variance coefficient in cyber bullying was calculated as $\mathrm{R}^{2}=.25$.

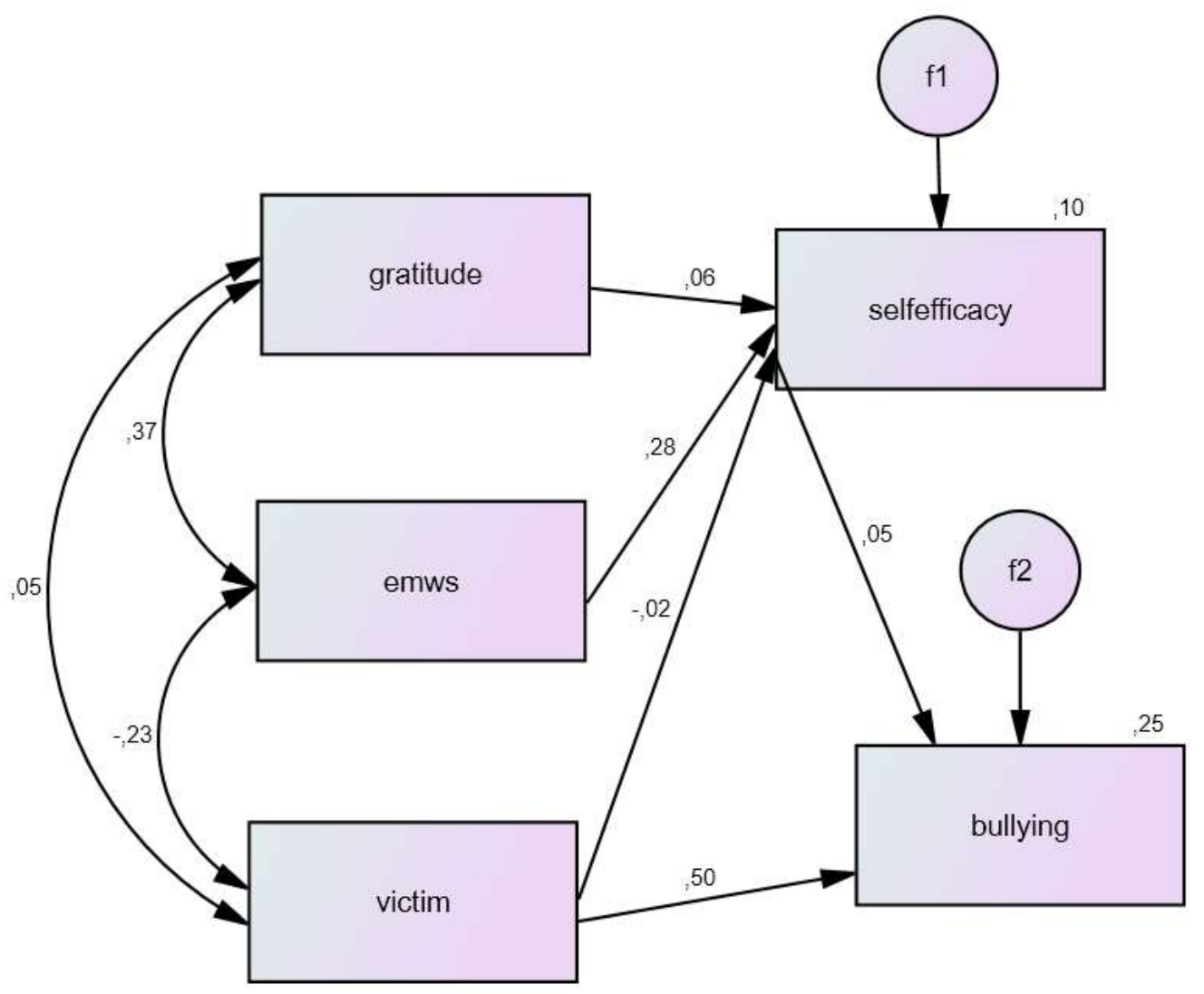

Figure 1. Standardized coefficient values for the model

\section{Discussion}

Results of the analysis indicated that the participants reported a high level of self-efficacy, a moderate level of gratitude, a high level of positive feelings and experiences about their childhood, and low level of experiencing cyber victimization and cyber bullying. A significant difference was found between the mean scores of cyber victimization in terms of gender. Females were significantly more likely to experience cyber victimization than males. The study reported that, while the early memories of warmth and safeness have a significant influence on self-efficacy; cyber victimization has a significant impact on cyber bullying.

As in the current study, Telef and Karaca (2011) indicated that adolescents have a high level of self-efficacy. The need for self-protection during adolescence is accompanied by a sense of confusion and conflict that has emerged through self-understanding efforts. Adolescents tend to deny their negative qualities when they try to protect their self. In a study conducted by Harper (1986) with adolescents, it was reported that while defining their self adolescents tend to see some qualities such as attractive, fun, sensitive, passionate and inquisitive as central and important qualities of their self- concept and they tend to see some qualities such as ugly, mean, depressive, nervous and selfish as the less important part of their self-concept.

In this study participants reported a low level of experiencing cyber victimization and cyber bullying. There can be many factors such as relationships with their family, attachment types, peer relationships, etc. that affect this situation result. It is known that individuals who have healthy attachment styles, have positive family relationships and are accepted by their peers are less likely to exhibit risky behaviors, and more likely to cope with difficulties in a healthy way (Hartup, 1996).

In a study conducted by Rey (2009) with 206 college students who have similar characteristics, it was aimed to determine variables that contribute to academic achievement. Study findings demonstrated that contentedness, 
warmth, and subjective well-being are positively correlated with general self-efficacy, academic self-efficacy and learning beliefs. In addition, contentedness and subjective well-being are found as important predictors of general self-efficacy and academic self-efficacy. The results of the current study also indicated that early memories of warmth and safeness predicted self-efficacy. Considering the positive relationships between these variables, findings of Rey's (2009) study supports the impact of early memories of warmth and safeness on self-efficacy.

The results of the current study indicated that cyber victimization is a predictor of cyber bullying. This finding is similar to the findings of the research which suggested that negative emotion predicts cyber victimization and cyber bullying positively (Peker, 2015). The lack of self-expression and social skills in cyber-victims who are exposed to cyber bullying may lead them to face negative or harmful acts while they are using information and communication technologies. Therefore, individuals with high negative emotions are more likely to face with cyber-bullying (Peker, 2015). Previous studies remarked that several negative feelings such as revenge (Dilber, 2013; Yaman \& Peker, 2012), anger and hostility (Arıcak, 2009, Pornari \& Wood, 2010) and aggression (Dilmaç, 2009) can be considered as the causes of bullying behavior. These finding also support the results of the current study.

This research is limited a particular sample: high school students. Further studies may collect data from different sample groups like those in pre-adolescence. The fact that self-efficacy has no significant influence on cyber bullying may be related to using of general self-efficacy as a predictor variable. Future studies may examine the predictive roles of different kinds of self-efficacy such as cyber bullying self-efficacy.

\section{Conclusion}

In the light of the research results, it is said that individuals should be supported on happy childhood passions in order to develop self-efficacy. When giving information about raising children to their families, they should pay attention to the development of self-efficacy so that they can raise individuals who can cope with difficulties, and what can be done about it. It can be said that one of the ways to prevent cyber bullying is to prevent cyber victimization. Therefore, professionals may develop interventions that focused on emotion management, coping with problems and difficulties and self expression to decrease experiencing cyber victimization.

\section{References}

Akça-Baştürk, E., Sayımer, İ., Ergül, S. (2015). Ortaokul öğrencilerinin sosyal medya kullanımları ve siber zorbalık deneyimleri: Ankara örneği. Global Media Journal TR Edition, 5, 10, 71-72.

Akın, A., Uysal, R., \& Çitemel, N. (2013). Çocukluk Dönemi Mutluluk/Huzur Anıları Ölçeğinin Türkçe formunun geçerlik ve güvenirlik çalışması. Uludağ Üniversitesi Eğitim Fakültesi Dergisi, 26(1), 71-80.

Akın, A., \& Yüksel, R. (2011, July). Validation of the Gratitude Questionnaire in Turkish. Paper presented at the 32th International Conference of the Stress and Anxiety Research Society (STAR), July, 18-20, Münster, Germany.

Arıcak, O. T. (2009). Psychiatric symptomatology as a predictor of cyberbullying among university students. Eurasian Journal of Educational Research, 34, 167- 184.

Arıcak, O.T., Tanrıkulu, T. ve Kınay, H. (2012). Siber mağduriyet ölçeği'nin ilk psikometrik bulguları, Akdeniz Eğitim Araştırmaları Dergisi, 6, 11, 1-6.

Bandura, A. (1997). Self-efficacy: The exercise of control. New York: Freeman.

Bandura, A. (1994). Self-efficacy. Encyclopedia of human behaviour, 4,7-81.

Bandura, A. (1986). Social foundations of thought and action: A social cognitive theory. Englewood Cliffs NJ: Prentice Hall.

Cleaver, H., Walker, S., \& Meadows, P. (2004). Assessing children's needs and circumstances: the impact of the assessment framework. London: Jessica Kingsley Publishers.

Dilmaç, B. (2009). Psychological Needs as a Predictor of Cyber-bullying: A Preliminary Report on College Students. EducationalSciences: Theory \& Practice. 93, 1291-1325.

Dilber, Y. (2013). Ergenlerde görülen siber zorba/mağdur yaşantılarının utanç/suçluluk ve intikam duyguları çerçevesinde incelenmesi. Yayımlanmamış Yüksek Lisans Tezi, Yeditepe Üniversitesi, İstanbul.

Dunn, J. (2004). Children's friendships: the beginnings of intimacy. Malden, MA, Blackwell.

Erikson, E. H. (1984). Insanın sekiz çağı, (B. Üstün and V. Şar, Çev.). Ankara: Birey-Toplum Yayınları. 
Evirgen, N. 2010. Aile içi örüntülerin çocukların algıları açısından incelenmesi. Yayınlanmamış Yüksek Lisans Tezi, Ankara Üniversitesi, Sosyal Bilimler Enstitüsü. Ankara.

Hall, G. S. (1904). Adolescence (Vol. 1-2). Englewood Cliffs, NJ: Prentice Hall.

Harter, S. (1986). Processes underlying the construction, maintenance, and enhancement of the self-concept of children. In J. Suls \& A. Greenwald (Eds.), Psychological Perspective on the self (Vo.l 3). Hillsdale, NJ: Erlbaum.

Hartup, W. W. (1996). The company they keep: friendships and their devolepmental significance. Child Development, 67, 1-13. https://doi.org/10.2307/1131681

Klein, M. (1999). Şükran ve Hased. (O Koçak- Y. Erten, Çev.). İstanbul: Metis Yayınları.

McKay, M., Fanning, P. (2014). Self-confidence. (F. G. Atay, Trans.). Ankara: Arkadaş Yayınevi.

Patchin, J. W., Hinduja, S. (2006). Bullies move beyond the schoolyard. A preliminary look at cyberbullying. Youth Violence and Juvenile Justice, 4, 2, 148-169. https://doi.org/10.1177/1541204006286288

Peker, A. (2015). Investigating the predictive role of negative affect on cyber bullying and victimization. Kastamonu Ĕ̈itim Dergisi, 23, 4, 1633-1646.

Peker, A., Eroğlu, Y., \& Ada, Ş. (2012). Ergenlerde siber zorbalığın ve mağduriyetin yordayıcılarının incelenmesi. Abant İzzet Baysal Üniversitesi Eğitim Fakültesi Dergisi.185-206.

Piko, B. F., Gibson, F. X., Luszcynska, A., Teközel, M. (2002). Does culture matter? Cross-cultural comparison of smoking patterns among adolescents. The $16^{\text {th }}$ Conference of the European Health Psychology Society-Proceeding.

Pornari, C. D., Wood, J. (2009). Peer and cyber aggression in secondary school students: the role of moral disengagement, hostile attribution bias, and outcome expectancies. Aggressive Behaviour, 36, 2, 81-94. https://doi.org/10.1002/ab.20336

Rey, D. (2009). The Relationship of Gratitude and Subjective Well-Being to SelfEfficacy and Control of Learning Beliefs Among College Students. Unpublished doctoral dissertation. University of Southern California.

Richter, A., Gilbert, P., \& McEwan, K. (2009). Development of an early memories of warmth and safeness scale and its relationship to psychopathology. Psychology and Psychotherapy: Theory, Research and Practice, 82, 171-184. https://doi.org/10.1348/147608308X395213

Santrock, J. W. (2014). Adolescence. (D. M. Siyez, ED. Trans. )Ankara: Nobel yayın.

Telef, B. B., Karaca, R. (2011). Adolescents' self-efficacy and psychological symptoms' investigation. Mustafa Kemal University Journal of Social Sciences Institute, 8, 16, 499-518.

Topçu, Ç., Erdur-Baker, Ö. (2010).The Revised Cyber Bullying Inventory (RCBI): validity and reliability studies. Procedia Social and Behavioral Sciences, 5, 660-664. https://doi.org/10.1016/j.sbspro.2010.07.161

Yaman, E. ve Peker, A. (2012). Ergenlerin siber zorbalık ve siber mağduriyete ilişkin algıları. Gaziantep Üniversitesi Sosyal Bilimler Dergisi, 11, 3, 819 -833. 